\title{
A University's perspectives on international partnership management
}

\author{
Shuangnan $\mathrm{He}^{1, \mathrm{a}^{*}}, \mathrm{Xu}$ Huang ${ }^{2, \mathrm{~b}}$ \\ ${ }^{1}$ Building 2 Silong Garden, Tiedong District, Anshan City, Liaoning Province, China \\ ${ }^{2} \mathrm{PA} 1$ 2BE, High Street, Paisley, Business School, University of the West of Scotland, UK

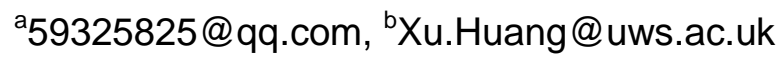

Keywords: Relationship marketing; Higher education; Partnership management; Partnership characteristics

\begin{abstract}
:
- Purpose: to explore the relationship management in universities

- Design/methodology/approach : Due to the exploring the management issues in partnership, the paper employed a case study approach that focused on a large, modern UK university, used a qualitative methods approach, from a subjectivist, interpretivist and inductive stance, carried out 13 interviews snowball sampling techniques

- Findings : this paper presents research findings in terms of partnership characteristics; partnership development process; type of partnership and measurement issue

- Research limitations/implications: this study is conducted in a single case setting wouldn't generalize findings to all universities; however, it is a pioneer study to reveal the relationship management between universities and its educational partners, which adds knowledge of relationship management in higher education sector.

- Practical implications: this study benefits to the practitioners in higher education because it helps transform knowledge to action

- Social implications: better managed relationship between universities and its educational partners, better we can make our students to be for themselves, relevant organization and whole society.

- Originality/value : this is the first study of expanding our knowledge of B2B relationship management into higher education setting
\end{abstract}

\section{Introduction}

The issue of relationship management of buyer-supplier or seller-customer are relatively well understood either in the practice or in the literature for private commercial companies (Christopher et al 1993, Christopher et al 2002, Buttle 1996, Peck et al 1999, Payne and Frow, 2005;2010) or public and non-profit organizations (Bussell, and Forbes 2006, Knowles and Gomes 2009, Hemsley-Brown and Oplatka 2006).Additionally, relationship management is important in terms of effective marketing management because

- Product and services can be duplicated, relationship can't be (Buttle 1996).

- Relationship provides substantial benefits to both parties (Ravald\&Grönroos, 1996).

- Relationship is viewed as strategic asset (Ford and Hakanson 2006).

- Relationship is a source of competitive advantage(Donaldson \&O'Toole2007;Ellis 2011).

However, whilst relationship marketing theory and practice have been advanced in commercial arenas (Buttle 1996), there is less research in the public and non-profit areas (Bussell and Forbes 2006), particularly with regard to universities.

The aim of this paper is to fill this gap in the literature. Whilst relationship management is a familiar concept, its application to the particular context of a UK university is less explored, furthermore, this paper contributes to drive more effective university - educational partnership management in practice. 
Therefore, the objectives of this paper are:

- To identify the characteristics of relationships of UWS and its educational partners

- To classify the types of relationship

- To explore determinants of good quality of relationship

\section{Literature Review}

Relationship Marketing. In order to better comprehend the relationship marketing, we begin with a short introduction of marketing. Marketing's leading international professional bodies are Chartered Institute of Marketing (CIM) in the UK and American Marketing Association (AMA), they define marketing as:

- "The management process responsible for identifying, anticipating and satisfying customer requirements profitably" (CIM,2011);

- "Marketing is the activity, set of institutions, and processes for creating, communicating, delivering, and exchanging offerings that have value for customers, clients, partners, and society at large" (AMA,2007);

Therefore, marketing is equated with marketing management. While other prominent scholar's argue various definitions of marketing from the philosophical perspective instead of process, such as marketing is the achievement of corporate goals through meeting and exceeding customer needs better than the competition (Jobber,2001)

As one of the established business and management discipline, marketing has developed accordingly since the world, society, technology, economics change over time. Different perspectives on marketing has been introduced: early and popular produced- based '4Ps' in 1960s, industrial/B2B marketing, social marketing, service marketing in 1970s, most notably 'relationship Marketing in the 1980s and 'service-dominant logic(S-D logic)'(Vargo and Lusch2004) of marketing in the mid of 2000s, social media marketing in late of 2000s and new marketing DNA (Harrigan et al 2011 )in 2011. However, as one of the dominant themes in the marketing subject area and literatures, relationship marketing (RM) has gained its popularity and shifted to widespread since 1991.

As one of the dominant themes in the marketing subject area and literatures, relationship marketing (RM) has gained its popularity and shifted to widespread since it emerge firstly in 1983. The concept of relationship marketing has been developed since the 1970s but the practice of RM has a long history. RM may be the oldest form of marketing, but least known. Historical research indicates that in the middle age businessman recognized that some customer were worth courting more seriously than others, richer customer would be offered credit terms, the poor paid cash (Buttle, 1996). In the late 1970s and the 1980s there is an emphasis on marketing relationships emerged in the marketing literature due to the dissatisfaction with the transactional marketing paradigm. Simultaneously but independently, researchers across Atlantic in the USA (for example, Wilson 1976; Bonoma et al. 1977; Jackson 1985) and Europe (Ford 1980; Hakansson 1982; Johanson and Mattsson 1984; Gummesson, 1987) began to look beyond the simple transaction and started to explore the notion of dyadic relationships. The concept of 'relationship marketing' emerged in 1983, was firstly defined by Berry (1983:25) in the service marketing context as: '... attracting, maintaining and - in multi-service organization-enhancing customer relationships', but the RM concept did not gain widespread access until the publication of the first RM book by Christopher et al(1991). One of the most influential features of the book was the concept of loyalty ladder, where strategies for organization were to be geared towards moving customers up the rungs of a ladder from 'suspects' to 'prospects' to ' first time customer' to 'repeat customer' to 'supporters' to 'advocates'.

Since 1990s, relationship marketing has received increasing attention. Its philosophy has moved companies from traditional marketing that focuses on the short-term transactional approach revolving around single and short-term events with a defined beginning and end, to a long-term, customer focused and mutually beneficial approach. Also in this period, RM was seen as a new marketing 
paradigm (Gronroos 1997). RM is a new marketing process focusing on how organisations can the effective, interactive exchange on information as a path through to build stronger customer loyalty to avoid price-based competition employed by both industrial and service sector. Its school of thoughts are derived from American (Berry 1983), Nordic service school (Gummesson 1997), IMP(Hakansson 1982), Anglo-Australian approach (Christopher, Payne\& Ballantyne 1991).Gronroos (1994:355) offers a comprehensive definition of dyadic relationships between parties which captures the nature of new marketing: "Relationship marketing is to establish, nurture and enhance relationships with customers and other partners, at a profit, sothat the objective of the partners involvedare met. This is achieved by a mutual exchange and fulfillment of promises".

Till today, various of relationship marketing models accommodate the notion of focal and its partnerships known as 'four partnership and ten relationships'(Morgan \& Hunt, 1994); six markets(Christopher \& Ballantyne, 1991) or '30 Rs'(Gummesson, 1999). Moreover, Harland et al(2004) identify eight types of relationship.

In attempt to better understanding in what constitute a relationship, Morgan and Hunt (1994) suggest successful RM require relationship commitment and trust, they are key mediating variables (KMV). In other words, they are at the heart of any successful relationship with customers. They theorise that commitment depends on four variables: relationship benefits, relationship termination costs, shared values and trust. Trust itself is dependent on three variables: shared values, communication and opportunistic behaviour. They finally suggest when firms attend to relationships by:

- Provide resources, opportunities and benefits that are superior to the offering of alternative partners

- Maintain high standards of corporate value

- Communicate valuable information

- Avoid taking malevolently advantage of their exchange partners (Morgan and Hunt 1994:34)

Encouraged by Morgan and Hunt (1994)'s pioneer work-commitment and trust theory, a number of researchers undertake studies on the components of relationships (Gupta 1983; Dwyer et al 1987; Juttner and Wehrli 1994; Dion et al 1995; Dawar et al 1996; Holm et al, 1996; Conway, 1996; Selnes 1998; Ali and Birley, 1998; Lin and Germain, 1998; Gummesson, 1999, Cousins 2002, Bloemer 2003, Leonidou et al 2006, Qureshi et al 2007), these component variables are: trust, commitment, satisfaction, value creation, reliance, long-term, communication, loyalty, mutual goals, cooperation, adaptation, atmosphere, inter-personal tie, understanding, power, risk, conflict, psychic distance, organizational arrangements and institutionalization, cultural fit/ clash, proneness, opportunistic behaviour, sharing information and experience, social capital,attitudes among partners, fairness, bond and so far. Although many factors have been identified in the literature, five seem to be the most commonly noted (Conway and Swift 2000): (i) commitment, (ii) trust, (iii) seller's customer orientation/empathy, (iv) experience/satisfaction, (v) communication.

Deriving from the idea of product life cycle (PLC) which is used in marketing planning to make predictions of future demand, profit expectations and changes in the competitive environment, a number of scholar have noted that business relationships also follow the distinct stages-introduction, exploration, growth, maturity, decline and end stages as the relationships develops over time.

$\mathrm{RM}$ is with its emphasis on retention and the ideal of win-win strategy, however, this subject is without critics: RM with a history of 20 years would be doing a gross injustice to the contributions previous generation of marketing scholars and practitioners have made knowledge and understanding of the process (Godson,2009); RM lacks conciseness because it can be interpreted in different ways: to some it begins and ends with CRM, to others it is all about keep customer and developing loyalty while others have seen it as a business philosophy that envelops the entire company (Palmer1996).

At last, there is no 'one size fits all' with RM. Baker (2000) states that 'it is now generally accepted that the relationship marketing approach has effectively extended the marketing concept into areas such as services and business to business setting, which were poorly served by the marketing 
management model based upon concepts of mass production, mass distribution and mass marketing essentially packaged consumer goods. At the same time, it has also been appreciated that many marketing exchanges are based upon low involvement transactions and that the two distinct approaches can co-exist' (Baker, 2000: 5). If the philosophy of the organisation is based on developing long-term sustainable competitive advantage, then the long-term approach must be adopted and relationship marketing shall be embraced.

Research methods. Due to the exploring the management issues in partnership, the paper employed a case study approach that focused on the University of the West of Scotland, a large, modern UK university, used a qualitative methods approach, from a subjectivist, interpretivist and inductive stance, carried out 13 interviews with the senior manager, academic staffs by snowball sampling techniques .

Research findings. The section highlights the findings from qualitative interviews and provides analysis. Interview topic guide comprises four sections regarding the educational partnership; therefore, all the results of each question in each section are reported respectively.

Outline of educational partnership. Fundamentally, UWS gets into educational partnering because of the stimulation of generating incomes from partnering activities. Behind this primary motivation, being a university, providing opportunities for students studying in a UK university, for staff development in both institutions and for joint research project is motivating trigger as well as its inspiration to be a global informed university (UWS 2010).

Opportunities for students, staff development, research is also a trigger to motivate UWS seeking international partners as students' population will be expanded and students' learning and life experience will be improved. At meantime, lecturers in both institutions are able to develop joint course or program customized the need of overseas students.

Next, interviewees are asked what objectives of partnering. It is a clear consensus that partnership aims to bring faculties into joint project, such as module design, joint funding application, and joint research project. Other important goals are to implement internationalization and global citizen strategy, to generate income, to diversify student population.

All the interviewees hold positive views on the partnering as it has significant impact on UWS. Finally, being an educational partner for both institutions, it shall have following characteristics:

- Share same or similar strategic objective with strategic planning and support;

- In Long term, ideally 5-8 years and more;

- With mutual benefits for both institutions and their students and staff;

- Be profitable;

- A reliable methods for recruiting international student and a reliable route to get a UK degree or learning experience;

- Be treated equally with respect;

- Formal relationship, contract-based;

- Independent on both sides' resource: one hand, UWS offers excellent teaching and learning, research; on other hand, there is a demand from student to receive UK education.

\section{Classification of partnership}

Simply, according to the interviewees, relationship is classified as strategic, developmental, maintained, potential partner, standard and Opportunistic partner from the answers from interviewees. 


\begin{tabular}{|l|l|l|}
\hline Classification & Sources & References \\
\hline Key strategic partner & 4 & 4 \\
\hline Developmental partner & 2 & 2 \\
\hline Maintained partner & 2 & 2 \\
\hline Potential partner & 1 & 1 \\
\hline service partner (standard recruitment) & 1 & 1 \\
\hline Opportunistic partner & 1 & 1
\end{tabular}

But, qualitative findings also suggest a partnership typology in figure 7.5:

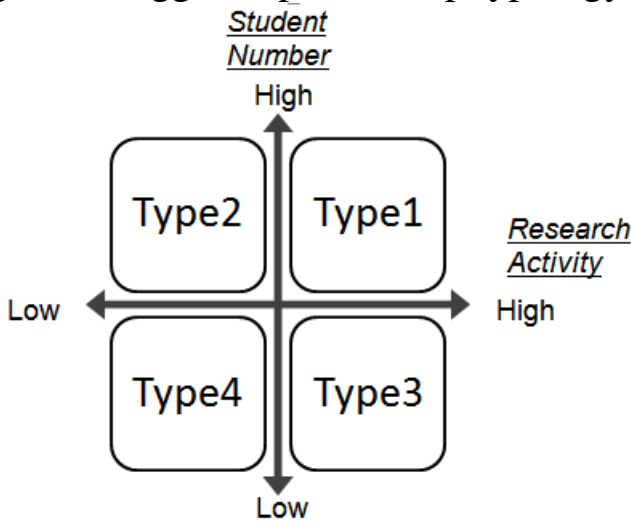

Figure. 1 Partnership typology

- Type 1 this is the ideal relationship for both of UWS and its partners, however, none of responds has confirm its existence, "we expect the number the students is high and increasing along with active cooperation in research and commercialisation"(4).

- Type 2 No.11 interviewee stated:" around 7-8 years ago, the student number that we sent to UWS is the highest, approximately 130 per year; however we didn't work on research related jobs".

- Type 3 No.10 interviewee thought: "now we have a broader area to work together e.g. joint research, funding application; However, I feel it doesn't contribute to increase the number of students coming to UWS".

- Type 4 No.5 illustrated:' we have some inactive partners because we don't work furthermore e.g. academic staff training develop or academic activities except a small number of students coming; therefore, we need to work out a solution'

\section{Relationship quality determinants}

Finally, interviewees are invited to speak up what determine the good quality relationship. Table 7.11 shows the findings that not surprisingly, trust is on the top of the list; strong offer stands the second place as good product packs support good relationship to be further developed; commitment, interpersonal relationship, levels of cooperation , mutual benefit and strategic support are considered important to determine a good quality relationship.

Table 1 Determinants of relationship quality

\begin{tabular}{|l|l|l|}
\hline Determinants of RQ & Sources & References \\
\hline trust & 4 & 4 \\
\hline strong offer & 3 & 3 \\
\hline commitment & 2 & 2 \\
\hline interpersonal relationship & 2 & 2 \\
\hline levels of cooperation & 2 & 2 \\
\hline
\end{tabular}




\begin{tabular}{|l|l|l|}
\hline mutual benefits & 2 & 2 \\
\hline strategic support & 2 & 2 \\
\hline adaptation & 1 & 1 \\
\hline Goals and objective & 1 & 1 \\
\hline Deliver & 1 & 1 \\
\hline Experience in internationalization & 1 & 1 \\
\hline Longevity & 1 & 1 \\
\hline motivated staff & 1 & 1 \\
\hline positive perceptions by students & 1 & 1 \\
\hline profitability & 1 & 1 \\
\hline Reliability & 1 & 1 \\
\hline Respect & 1 & 1 \\
\hline Responsiveness & 1 & 1 \\
\hline confident & 1 & 1 \\
\hline
\end{tabular}

\section{Conclusion}

The paper used qualitative methods to explore the university-educational typology, and measurement issue. But the models that are presented in section 5 are needed to be tested in quantitative manner in the future. Since this study was conducted in the single university, the research has its limitation that is the research findings can't be generalized to all universities. At the end, the researchers call for more case studies in a number of universities.

\section{References}

Buttle, F. (1996). Relationship marketing: theory and practice .London: SAGE.

Christopher, M., Payne, A., \& Ballantyne, D. (2002). Relationship marketing: creating shareholder value . Oxford: Butterworth-Heinemann.

Christopher, M., Payne, A., Ballantyne, D., \& Marketing, C. I. of. (1993). Relationship marketing: bringing quality, customer service, and marketing together . Oxford:Butterworth-Heinemann.

Dion, P., Easterling, D. and Miller, S. J., (1995). 'What is Really Necessary in Buyer/Seller Relationships?’ Industrial Marketing Management, 24(1).1-9.

Doherty, A.M. \& Alexander, N., (2004). Relationship development in international retail franchising: Case study evidence from the UK fashion sector. European Journal of Marketing, 38(9/10).1215-1235.

Donaldson, B. \& O'Toole, T., (2007). Strategic Market Relationships: From Strategy to Implementation, 2nd Ed. John Wiley \& Sons Ltd., Chichester

Dwyer, F.R., Schurr, P.H. \& Oh, S., (1987). “Developing Buyer-Seller Relationships”. Journal of Marketing, 51(2), 11

Edmondson, A. C., \& McManus, S. E. 2007. Methodological fit in organizational field research. Academy of Management Review: In press.

Ford, D. (1980), “The development of buyer-seller relationships in industrial markets", European Journal of Marketing, 14: 339-54.

Ford, D. and H. Hakanson (2006), "IMP - some things achieved: much more to do," European Journal of Marketing, 40 (3/4): 248-58 
Friman, M. et al., 2002. An analysis of international business-to-business relationships based on the Commitment-Trust theory. Industrial Marketing Management, 31(5).403-409.

Ghauri, P.N. \& Grønhaug, K. (2005), Research Methods In Business Studies: A Practical Guide, $3^{\text {rd }}$ ed., Harlow: Pearson Education.

Godson, M.( 2009), Relationship Marketing, Oxford University Press, Oxford

Gon, W. \& Cha, Y.( 2002). Antecedents and consequences of relationship quality in hotel industry. Environmental Sciences, 21:321-338. 